limited opportunity, not necessarily a gateway to the best the world affords. This may prove true of refugee settlement in particular. For refugees, a higher degree of tolerance of hard conditions has been assumed. Will it work out that way?

A scientific inquiry in each major area proposed for settlement cannot stop short of the goal of acceptable livings. Granted that there must be wide tolerance at first on the part of almost all settlers, can an inventory of resources, area by area, assure them diversified production and enlargement of opportunity with endurably brief delay? Since most areas of potential settlement are marginal, can scientific inquiry reduce the risks ? One may be sure that vast sums will not be spent in the post-war years upon doles to settlers who are badly located. There is every reason, however, why initial aid should be given to well-placed units who will add to the resources and taxable wealth of the countries of their adoption.

The abundance of unused land strikes every observer, yet it is the scarcity of commercially valuable unused land that intensifies the problem. The scientific study of settlement has become to a large degree a study of unused land. What keeps it out of production ? Is the soil deficient ? Is the water supply undependable? Are the required cultivation techniques peculiar? What is the natural unbalance that must be corrected by scientific study and treatment? The tsetse fly, natural versus artificial vegetation, extreme price changes and soil erosion are among the examples we have mentioned.

No less important is a study in national psychologies. What is the attitude, country by country, toward the foreigner? What part in the shaping or retention of a recognized national attitude is played by experience with groups already established? Are the examples of Colonia Tovar, Cyrenaica and São Francisco correctly interpreted ? What is the peculiar nature of the essential political processes in each country? How do the variant political processes play upon or determine migration policies ? What are the specific economic equivalents of migration in industry and trade?

When the answers to these and other questions are given, not in the terms of a single specialty, but in the terms of a social and political mosaic, country by country, the science of settlement will have reached maturity. Sophistication of the investigator plays a part in finding practical answers: he must have that "nice tact of circumstances" which enables him to determine reasonably well what specific groups of men can do, or will do, or may be persuaded to do.

\footnotetext{
1 Rasmussen, W. D., Colonia Tovar, Venezuela, "Agric. Hist", 17, 156 (1943).

${ }^{2}$ Cumberland, K., Geol. Rev., 84, 77 (1944).

swynnerton, C. F. M., "How Forestry May Assist towards the Control of the Tsetse Fliss". Appendix II in Troup's "Colonia Forest Administration", $439^{\circ}$ (London: Oxford University Press, 1940.)

- Gillman, C., "A Reconnaissance Survey of the Hydrology of Tangan yika Territory in its Geographical Settings", Tanganyika Territor 1943.)

J. Franklin Inst., 237, 251 (1944). "Crist, R. E., "Cultural Cross Currents in the Valley of the Rio
Säo Francisco", Geol. Rev. (1944).

" "La Vida en la Amazonia Peruana" (1944).

" "La Escasez de Tierras Cultivadas y sus Consecuencias", in "Tierra y Población en el Peru" (Lima, 1938).

- James, P. E., Michigan Academy Sci., Arts and Letters, 25, 385 (1939).

${ }^{10}$ Diffle, B. W., Hispanic Amer. Hist. Rev., 20, 426 (1940).

1 Forsyth, W. D., "The Myth of Open Spaces", 62 (1942).

${ }^{12}$ Alsberg, C. "The Food Supply in the Migration Process", in "Limits of Land Settlement", 50 (1937).

13 Coulter, J. W., "Fiji : Little India of the Pacife"”, 116 (1942).
}

\section{SCIENTIFIC CENTENARIES IN 1945}

\author{
By ENG.CAPT. EDGAR C. SMITH, O.B.E., R.N.
}

A REVIEW of the scientific centenaries which will A occur in 1945 may well begin with a quotation from the autobiographical notes of the English mathematician John Wallis (1616-1703), written when he was eighty: "About the year 1645," he wrote, "while I lived in London... I had the opportunity of being acquainted with divers worthy persons, inquisitive into natural philosophy, and other parts of human learning; and particularly of what hath been called the New Philosophy, or Experimental Philosophy. We did by agreements, divers of us, meet weekly in London on a certain day, to treat and discourse of such affairs. . . These meetings we held sometimes at Dr. Goddard's lodgings in Wood Street . . on occasion of his keoping an operator in his house for grinding lenses for telescopes and microscopes; sometimes at a convenient place in Cheapside, and sometimes at Gresham College, or some place near adjoyning.

"Our business was (precluding matters of theology and state-affairs) to discourse and consider of Philosophical Enquiries, and such as related thereunto: as Physick, Anatomy, Geometry, Astronomy, Navigation, Staticks, Magneticks, Chymicks, Mechanicks, and natural Experiments ; with the state of those studies, as then cultivated at home and abroad. ..."

From those gatherings and others at Oxford sprang the Royal Society, the first official record of which is a memorandum relating to a meeting on Nov. 28 , 1660, held in Gresham College. "W. G." wrote:

"At Gresham College a learned knott,

Unparallel'd designs have lay'd

To make themselves a corporation

And know all things by demonstration."

Of the various subjects Wallis named, "Chymicks" was one which perhaps most needed the experimentalist to remove it from the realm of mystery. Jean Rey, a Frenchman, appears to have been such a man. He was born in what is now the Department of Dordogne; he studied medicine, corresponded with learned men and worked at practical chemistry. His death took place three hundred years ago, but in 1630, fifteen years before he died, he published "Essays de Jean Rey sur la Recerche de la cause pour laquelle l'Estain et le Plomb augmentent de poids quand on les calcine", which was thought worthy of republishing in 1908 and was reviewed in Nature of July 9, 1908. This memoir appears to anticipate the discoveries and views of Lavoisier by nearly a century and a half, but A. N. Meldrum (Nature, July 30, 1908) states that there is little evidence that Rey made. experiments of any value in support of his views.

The year in which Rey died, his countryman Nicolas Lèmery (1645-1715) was born at Rouen. He lectured in Paris, spent some time in England as a Protestant refugee, but having embraced Catholicism, returned to France and was given a seat in the Royal Academy of Sciences. To-day he is remembered for his "Cours de chimie" (1675), which went through many editions and was translated into several languages. "The fine imaginations of other philosophers", he wrote, "concerning their physical principles may elevate the spirit by their grand ideas, 
but they prove nothing demonstratively. And, as chemistry is a science of observation, it can only be based on what is palpable and demonstrative." The year 1645 has sometimes been given as the birth yrear of the English chemist John Mayow, but as Dr. Douglas McKie has shown, he was baptised in Morval Church, Cornwall, on December 21, 1641.

Passing to 1745, we have the births of Gahn, the Swedish chemist, of Etienne Montgolfier, the younger of the two pioneers of ballooning, of Schröter, whom Miss Clerke referred to as "the Herschel of Germany", and of the much more famous Volta. Johan Gottlieb Gahn was a student under Bergmann, a contemporary of Scheele and an associate of Berzelius. He was a chemist before he was a mineralogist, and a mineralogist before he became a metallurgist. Expert with the blowpipe, he was the first to isolate manganese. Montgolfier, too, was a chemist, as well as being a papermaker, and it was reading Priestley's memoirs which gave him some of his ideas. The monument erected at Annonay in $\mathbf{1 8 8 3}$ honours both brothers, and was erected to commemorate the centenary of their first full-seale experiment with a 'machine aërostatique'.

Johann Hieronymus Schröter (1745-1816) was a worthy representative of that great band of amateurs who have furthered the cause of astronomy. Born at Erfurt, he became a law student at Göttingen and knew Herschel's musical family at Hanover. When thirty-three he was made magistrate at Lilienthal near Bremen, and there in his spare time studied the moon and planets. It was Schröter's assistant, K. L. Harding (1775-1834), who discovered the minor planet Juno, and when Harding went to Göttingen his place was taken by the young supercargo, Friedrich Wilhelm Bessel. Early in 1813, Bremen was occupied by the French, and in April Schröter saw his observatory pillaged and his books and writings burnt. $\mathrm{He}_{\theta}$ died three years later, a broken man. Though Volta, too, lived through the whole of the Napoleonic Wars, he suffered no such catastrophe. $\mathrm{He}$ was born at Como on February 18, 1745, and there he died in 1827. In 1899 and again in 1927, great international gatherings of scientific men were held at Como to mark the centenary of his most important discovery and the centenary of his death. Among Great Britain's representatives at the second meeting were Sir J. J. Thomson, Lord Rutherford and Sir Arthur Eddington.

Of the men of science who died a hundred years ago, few were better known than John Frederick Daniell, who expired suddenly on Maroh 13, at a Council meeting of the Royal Society, of which he was at the time the foreign secretary. London born and bred, and educated privately, his devotion to science led to his admission to the Royal Society at the age of twenty-three. He worked with W. T. Brande, and on the establishment of King's College, London, was appointed to the chair of chemistry. The invention of the Daniell cell brought him the Copley Medal of the Royal Society. While Daniell was busy with his electrical experiments, the retired French watchmaker Jean Charles Athanase Peltier was engaged in much the same pursuits, discovering in 1834 the Peltier effect, the reverse of that made known thirteen years earlier by Seebeck. Peltier was born in 1785 and died on October 27, 1845. Nine days before this, the last of the Italian-French family of astronomers, Jacques Dominique Cassini, died at the age of ninety-seven. His father, Cesar François, had died in 1784 when seventy, his grandfather Jacques in 1756 when seventy-nine and his greatgrandfather Jean Dominique in 1712 at the age of eighty-seven. For a hundred and twenty years a Cassini had been connected with the Paris Observatory, and the record was broken only by the upheaval of the French Revolution. The second and third Cassinis were especially active in geodesy, the great map of France being largely their work. After his dismissal from the Observatory in 1793 by the National Convention, Jacques Dominique, Compte de Cassini, retired to his estate and abandoned astronomy entirely.

Astronomers born in 1845 include Sir William Henry Mahoney Christie (died 1922), AstronomerRoyal from 1881 until 1910; Sir George Howard Darwin (died 1912), Plumian professor of astronomy and experimental philosophy at Cambridge from 1883 until 1912; Arthur Cowper Ranyard (died 1894), a founder of the London Mathematical Society and secretary of the Royal Astronomical Society, through whose efforts the tablet to Jeremiah Horrocks in Westminster Abbey was erected, and the distin. guished director of the Paris Observatory, François Felix Tisserand (died 1896). The monument erected at Nuits-Saint-Georges to Tisserand was described and illustrated in Nature of November 23, 1899. His "Traite de Mécanique Celeste", it has been said, furnishes a faithful and complete résumé of the state of that department of astronomy at the end of the nineteenth century. In the United States, the year 1845 saw the completion of the Cincinnati Observa. tory, the first of any size in that country. Its erection was due to Ormsby MacKnight Mitchel, the author of "The Orbs of Heaven", a book which greatly influenced Sir Robert Ball when a boy.

Other workers in the exact seiences born in 1845 were William Kingdom Clifford, Gabriel Lippmann and Wilhelm Conrad von Röntgen. In the days of Huxley, Tyndall, Herbert Spencer and Leslie Stephen, there was no more notable figure in intellectual circles than Clifford, who died at the early age of thirty-four after occupying for eight years the chair of applied mathematics in University College, London. "He was admitted on all hands", said the Athenceum, "to be the most remarkable mathematician of his generation, and promised to be a second Cayley." Gabriel Lippmann, For.Mem.R.S., who died aboard the La France on July 13, 1921, when on his way home from Canada, was born in the Grand Duchy of Luxemburg, but practically all his life was spent in Paris. In 1886 he became director of the Physical Research Laboratory at the Sorbonne, in 1908 was awarded the Nobel Prize for Physics and in 1912 was elected president of the Paris Academy of Sciences. His process of colour photography was announced in 1891 .

Clifford's name is known to relatively very few general readers to-day; Lippmann's to a more numerous but select circle; but the name of Röntgen is known everywhere. While March 27 will mark the centenary of his birth at Lennep, a few miles to the west of Düsseldorf, November 8 will be the fiftieth anniversary of his discovery at Würzburg of Röntgen rays, or as he called them, 'X-rays'. "Nov. 8 , 1895", said Silvanus Thompson, "will ever be memorable in the history of science. On that day a light, which so far as human observation goes, never was on land or sea, was observed." The discovery was given to the world in Röntgen's paper, "Über eine neue Art von Strshlen", read to the 
Physical-Medical Society of Würzburg in December. There was universal recognition of the significance of the step made, and a translation of the paper was published in Nature of January 23, 1896. In 1897 the Röntgen Society was founded, but has since (1927) been amalgamated with the British Institute of Radiology. Though born in the Ruhr, Röntgen was educated in Holland and Switzerland. His appointments took him to Würzburg, Strasbourg, Hohenheim and Giessen, then back to Würzburg and finally to Munich, where he died on February 10 , 1023.

Passing from the realms of the pure sciences to those of engineering, the year 1845 saw the birth of the versatile inventor and investigator Beauchamp Tower (1845-1905), who will long be remembered for his researches on lubrication carried out for the Institution of Mechanical Engineers. Carl Gustav Patrik de Laval (1845-1913), the Swedish pioneer of the steam turbine; Friedrich von Hefner-Alteneck (1845-1904), the German electrical engineer, and the Swiss hydraulic engineer Theodore Turrettini (1845-1916), were all equally versatile and inventive. With Lord Kelvin, Maseart, Unwin, Sellers and George Forbes, Turrettini was one of the Commission appointed in 1891 to deal with the problem of harnessing Niagara Falls. Karl Benz (1845-1929), the German pioneer of the motor-car, had few of the advantages enjoyed by the foregoing; but he left his mark on a growing industry. He began life as a workman in a Karlsruhe machine-shop, but at the age of twenty-six started on his own at Mannheim. There he produced, in 1885 , one of the first vehicles driven by an internal combustion engine. In an entirely different field, we have the names of three eminent British naval architects, Sir William White (1845-1913), Dr. Francis Elgar (1845-1909) and William John (1845-90). All three were shipwright apprentices in the Royal Dockyards, and all three entered the famous Royal Sehool of Naval Architecture and Marine Engineering at South Kensington, in 1864, the year it was opened. For a time their careers ran on parallel lines, but afterwards diverged, John becoming the manager of the Shipbuilding Yard at Barrow, now a part of Messrs. Vickers-Armstrongs, Eilgar being nominated the first professor of naval arehitecture in the University of Glasgow, while White was for nearly twenty years director of naval construction at the Admiralty. By their labours Great Britain was repaid a thousand-fold what the Admiralty had spent on their education.

There was plenty of scientific activity in 1845 , though not on the scele of to-day. For its fifteenth meeting the British Association made its second visit to Cambridge. Sir John Herschel was president, and one of the papers was by Joule, who described his paddle-wheel experiments for determining the relation between heat and work. After the gathering, Herschel wrote to Mrs. Somerville in Rome: "We had a full and very satisfactory meoting at Cambridge of the British Association with a full attendance of continental magnetists and meteorologists, and within these few days I have learned that our Government meant to grant all our requests and continue the magnetic and meteorologieal observations". One of the foreigners present was Von Buch, whom all the leading men of seience had met at Dr. Fitton's in London. "At Murehison's request", wrote A. C. Ramsay, "I took Von Buch to Cambridge on the outside of the mail coach from the head of the Haymarket. His luggage eonsisted only of a small baize bag, which held a clean shirt and clean silk stockings. He wore knee-breeches and shoes." Airy, of course, was at Cambridge and in the Senate House lectured on terrestrial magnetiam, keeping his audience, as one writer said, "quite enchained for above two hours". Airy was given to long lectures, and on one occasion at the Royal Institution, his chairman, the Prince Consort, went to sleep. He was indefatigable. As if the directing of the astronomical, magnetical and meteorological work at Greenwich was insufficient occupation, in $\mathbf{1 8 4 5}$ he served on the Railway Gauge Commission and a Harbour Commission, planned saw-mills for a dockyard, descended Cornish mines, nearly fainting at the bottom of one, and ascending another by Loam's man engine, "the finest operation that I ever saw", from France sent John Murray an account of the Cherbourg breakwater for Murray's "Handbook" and later in the year dined a York with George Hudson, the 'railway king'.

Early in 1845 at Cambridge, a young man of twenty-one was second wrangler and first Smith's prizeman ; one examiner remarking to another, "You and I are about fit to mend his pens". From the University the future Lord Kelvin went to Paris, worked in Regnault's laboratory, and through reading a paper of Clapeyron's learnt about Sadi Carnot's essay, but it took him three years to obtain a copy. Another Cambridge wrangler, Adams, of somewhat more mature age, twenty-six, the son of a Cornish farmer, in 1845 was devoting all his time to his self. imposed task of trying to discover if the behaviour of Uranus could be explained by the presence of a planet no one had ever seen. A young French astronomer, Leverrier, was doing the same thing. Both arrived at the same conclusion, and next year a German astronomer found the planet. A very unscientific controversy arose in scientific circles, but to-day the world honours Adams and Leverrier alike.

The Royal Society in 1845 was in the midst of the long presidency of Spencer Joshua Alwyne Compton, second Marquis of Northampton, who following Davy's practice provided the fellows with tea. Samuel Hunter Christie, father of Sir William, was the secretary, John William Lubbock was treasurer, and after Daniell's death, Colonel Sabine was foreign secretary. The Copley Medal in $\mathbf{1 8 4 5}$ was awarded to the Belgian naturalist Theodor Schwann, the Royal Medals to Airy and to the apparently forgotten Thomas Snow Beck, who had investigated the nerves of the uterus. At the Royal Institution, Faraday was pursuing his patient investigations, and in his diary under September 13, 1845, noted his success with glass and magnets, writing: "BUT when contrary magnetic poles were on the same side there was an effect produced on the polarised ray, and thus magnetie force and light were proved to have relation to each other".

As to the other scientific bodies, the Chemical Society, then in its fourth year, was presided over by Thomas Graham ; the Royal Astronomical Society by Airy, who presented its Gold Medal to that very seientific naval officer Admiral William Henry Smyth, while the Geological Society elected as its president the "mild unpretending, differential" Leonard Horner. Geology was still a thorn in the flesh to the strictly orthodox, and on August 3, 1845, Mrs. Somer ville wrote to her son: "The papers (I mean The Times) are full of abuse of Mr. Sedgwick and Dr. Buckland, bat their adversaries write such nonsense that it 
matters little". On April 1 the Geological Survey had been finally taken away from the Master-General and Board of Ordnance and placed "under the direction and supervision of the First Commissioner of Her Majesty's Woods, Forests, Land Revenues, Works and Buildings". The most important geological book of the year was the fine volume by Murchison and his associates, "The Geology of Russia in Europe and the Ural Mountains", dedicated to the Czar and containing coloured gold pinpointed maps showing the mineral deposits from the northern extremity of the Urals to the Donetz Basin.

Experimental science still languished at Oxford and Cambridge, and in spite of the work of Graham at University College and of Daniell at King's College, London was sadly in need of chemical laboratories. Largely through the Prince Consort, this need was met in 1845 by the opening in Oxford Street of the Royal College of Chemistry, where twenty-six students gathered to sit at the feet of a young privat-docent from Bonn, August Wilhelm Hofmann. In those faroff days, there was no talk of "blood and iron", "mailed fists" or "racial superiority", and there was free and friendly intercourse between German and British men of science, to the great advantage of both. Hofmann remained in London until 1864, but he came back later, his last appearance being in 1884, when he presided over the dinner given in honour of one of his most famous pupils, William Henry Perkin.

By 1845 the peace had lasted thirty years and there was money to spend on all sorts of projects. The railway mania had set in, and Robert Stephenson was returning big cheques sent to him more or less as bribes. Some half a dozen railway lines, including those between Bristol and Gloucester, London and Cambridge and Manchester and Sheffield, were opened during the year, and as the railways spread so did the electric telegraphs. For a shilling, visitors to Paddington or Slough could see "this interesting and most extraordinary Apparatus by which upwards of 50 SIGNALS can be transmitted to a Distance of 280,000 miles in ONE. MINUTE'. The best advertisement, however, was the announcement of the arrest at Paddington through the use of the telegraph of the Slough murderer John Tawell. For the first time, too, a newspaper published a report of a meeting transmitted by electricity. Two years before, Colt, of revolver fame, had laid a submarine cable in New York harbour, and in Britain the Bretts were dreaming of a cable between England and France. Sea transport was undergoing a revolution. Steam vessels were found everywhere, iron shipbuilding was becoming an industry, and the trials of H.M.S. Rattler in 1845 showed the pioneers that screw propulsion was possible for even the stately three-decker line-of-battleship. By the spring, the famous iron screw steamer Great Britain, once called the Mammoth, was nearing completion, and on April 23, 1845, The Times said: "Yesterday Her Majesty and Prince Albert paid their contemplated visit to this extraordinary vessel". Brunel had the honour of explaining everything to the Royal party, and Francis Pettit Smith, otherwise "Screw" Smith, presented "a very beautiful model in gold, in an appropriate case, of the propeller he had recently fitted to Her Majesty's new tender yacht Fairy". The Great Britain sailed on her maiden voyage on July 26, 1845, and so opened another chapter in trans-Atlantic travel.

\section{OBITUARIES}

\author{
Sir John Fox, C.B., O.B.E., F.R.S.
}

JohN $J_{A C O B}$ Fox, eldest son of Mark and Hannah Fox, was born in London on April 12, 1874, and died on November 28, 1944. He received his scientific education at the Royal College of Science, South Kensington, and at Queen Mary College, London, taking the B.Sc. degree by research in 1908 and the D.Sc. degree two years later. $\mathrm{He}$ was elected a fellow of the Royal Institute of Chemistry in 1916. $\mathrm{He}$ entered the Government service in 1896 and was appointed to the permanent staff of the Government Laboratory in 1904. He became superintending chemist in 1920, deputy Government chemist in 1929 and Government chemist in 1936.

During his official career, Fox was called upon to undertake work concerning a number of problems of interest not only to Government departments but also to the general public. Among these the following may be mentioned: the possibility of substituting for white lead either less-soluble compounds of lead or 'leadless' glaze; the causes of the decay of buildings; the pollution of rivers by drainage from tarred roads; the cleaning and restoration of wall paintings. His encyclopædic knowledge of organic chemistry and his sound judgment were called into play in organizing the sections of the Laboratory set up to advise the Board of Customs and Excise in the administration of the Safeguarding of Industries Act and of the duties on silk and artificial silk and on hydrocarbon oils. As Government chemist he was chairman of the Road Tar Research Committee and of the Committee on Physico-chemical Problems of the Building Research Board. In 1939 he threw himself with great energy into scientific matters connected with the prosecution of the War. This aspect of the work of his last years cannot yet be described in detail, but it can be stated that he served on numerous departmental committees and was a member of the Hydrocarbon Oil Duties Committee at the time of his death.

Fox found time to undertake a great deal of research. In his early years his mind turned to organic chemistry, and in this period he published researches in the acridine series and on the derivatives of 8-hydroxyquinoline and was joint author of the discovery of a new aromatic hydrocarbon diphenylene. Later he was interested in spectroscopy and its relation to molecular structure. The ultraviolet absorption spectra of alkaloids, sulphur, the halogens and light elements was studied. His work on the infra-red absorption spectra of diamond and of some carbon compounds, carried out in collaboration with colleagues in the Government Laboratory, led to the recognition of two types of diamond and to the elucidation of some difficult problems in analytical chemistry. Difficulties arising in his official work suggested researches on the solubility of lead sulphate in ammonium, potassium and sodium acetates, on mannito-boric acid and on the composition of some medieval waxes. He also published researches on new and improved methods of analysis.

Fox had a very alert mind, a photographic memory and abundant energy. In addition to the numerous research institutions to which he was appointed in his official capacity, he gave his time freely to the work of scientific societies. He was a past president of the Royal Institute of Chemistry, of the Oil and Colour Chemists' Association and a vice-president of 